\title{
RUMAH WISATA BATIK MANGROVE: KEMBALI KE AWAL (MEMPERKENALKAN BATIK MANGROVE SEBAGAI WARISAN BUDAYA)
}

\author{
Karina Adelia ${ }^{1)}$, Mieke Choandi ${ }^{2)}$ \\ 1)Program Studi S1 Arsitektur, Fakultas Teknik, Universitas Tarumanagara, karinardelia20@gmail.com \\ 2)Program Studi S1 Arsitektur, Fakultas Teknik, Universitas Tarumanagara, miekec@ft.untar.ac.id
}

Masuk: 25-07-2021, revisi: 15-08-2021, diterima untuk diterbitkan: 23-10-2021

\begin{abstract}
Abstrak
Batik merupakan salah satu warisan Bangsa Indonesia dan keberadaannya kini telah menjadi identitas kita. Namun seiring berjalannya waktu, batik hanya dianggap sebagai pakaian resmi yang hanya digunakan pada waktu-waktu tertentu saaj. Minimnya penggunaan batik dalam kehidupan sehari-hari menjadikannya kian dilupakan dan kurang diminati oleh generasi muda. Maraknya industri fast fashion yang dianggap lebih trendi menjadikan batik tidak lagi dikenal sebagai pakaian sehari-hari. Padahal, industri fast fashion ini kurang lebih telah membawa dampak pada kerusakan alam akibat penggunaan bahan baku sandang yang kurang ramah lingkungan. Perkembangan di bidang fashion ini juga membawa pengaruh pada produksi batik yang kurang ramah lingkungan di mana bahan pewarna maupun kainnya menggunakan bahan yang kurang ramah lingkungan. Pada tahun 2013 muncul komunitas batik mangrove yang bertujuan menghadirkan kembali batik yang ramah lingkungan sekaligus dapat membantu ekosistem hutan mangrove. Batik mangrove ini menggunakan limbah mangrove seperti batang, akar, serta daunnya yang diproses sedemikian rupa sehingga dapat dijadikan bahan pewarna pengganti pewarna sintetis yang tidak ramah lingkungan. Proyek rumah wisata batik mangrove ini diharapkan dapat menjadi wadah bagi komunitas pembatik mengrove untuk kembali eksis di kalangan masyarakat. Salah satu caranya ialah dengan menyediakan tempat workshop agar masyarakat dapat mengenal kembali batik mangrove dan langsung merasakan praktik membatik. Lebih jauh dari itu, rumah wisata batik mangrove ini menghadirkan area daur ulang untuk mendukung memberikan perbaikan dan peningkatan kualitas lingkungan di sekitarnya.
\end{abstract}

Kata kunci: batik; batik mangrove; industri fast fashion

\begin{abstract}
Batik is one of the heritages of the Indonesian nation and its existence has now become our identity. But over time, batik is only considered as formal clothing that is only used at certain times. The lack of use of batik in everyday life makes it increasingly forgotten and less attractive to the younger generation. The rise of the fast fashion industry which is considered more trendy makes batik no longer known as everyday wear. In fact, the fast fashion industry has more or less had an impact on natural damage due to the use of clothing raw materials that are less environmentally friendly. This development in the fashion sector also has an impact on the production of batik which is less environmentally friendly where the dyes and fabrics use materials that are less environmentally friendly. In 2013 the mangrove batik community emerged with the aim of bringing back environmentally friendly batik and at the same time helping the mangrove forest ecosystem. This mangrove batik uses mangrove waste such as stems, roots, and leaves which are processed in such a way that it can be used as a substitute for synthetic dyes that are not environmentally friendly. This mangrove batik tourism house project is expected to be a forum for the mangrove batik community to return to exist in the community. One way is to provide a place for workshops so that people can get to know mangrove batik and directly experience the practice of batik. Furthermore, this mangrove batik tourism house presents a recycling area to support providing improvements and enhancements to the quality of the surrounding environment.
\end{abstract}

Keywords: batik; mangrove batik; fast fashion industry 


\section{PENDAHULUAN}

\section{Industri Fast Fashion dan Pengaruhnya pada Lingkungan}

Dalam beberapa tahun terakhir, industri tekstil telah berkembang dengan sangat pesat dan diidentifikasi sebagai salah satu kontributor utama dari permasalahan mikroplastik yang memasuki lautan. Diperkirakan sekitar setengan juta ton mikrofiber plastik yang terlepas selama pencucian dari tekstik berbasis plastik (poliester, nilon, maupun akrilik) berakhir di lautan setiap tahunnya. Selain itu, sistem tekstil seperti ini juga memberikan dampak negatif bagi para pekerja. Tak jarang, para pekerja harus bekerja di lingkungan yang berbahaya karena proses tekstil mengandung zat berbahaya dan tidak aman.

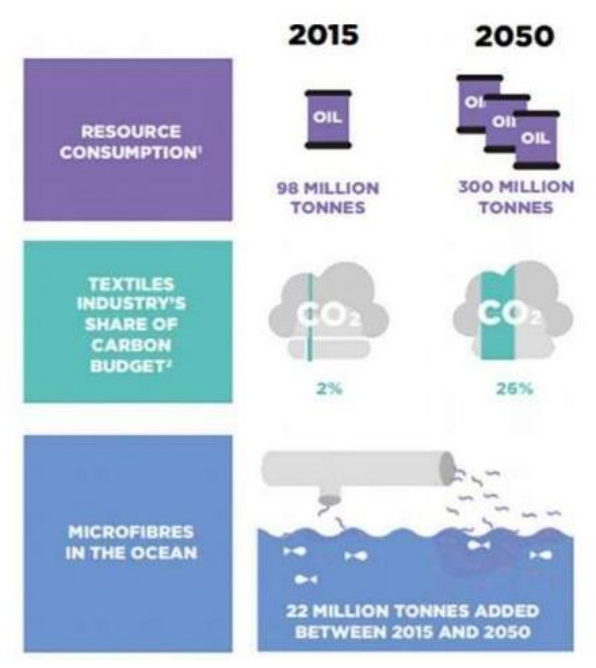

Gambar 1. Dampak Invasi Fashion dalam Industri Tekstil Sumber : Pulse of the Passion Report, 2018

Dapat dilihat dari grafik di atas bahwa diperkirakan pada tahun 2050, sebanyak 22 milyar ton mikrofiber akan bertambah akibat industri fast fashion dengan zat yang berbahaya yang terus diproduksi secara massal.

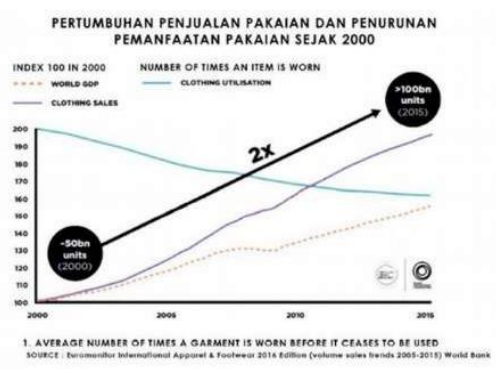

Gambar 2 Grafik Pertumbuhan Penjualan Pakaian dan Penurunan pemanfaatan Pakaian sejak 2000 Sumber : Eurimonitor

Perkembangan industri mode yang pesat ini ternyata tak juga diimbangi dengan minat masyarakat dalam mengelola pakaian mereka. Penurunan pemanfaatan pakaian dari tahun 2000 hingga tahun 2015 kian menurun. Hal ini membuktikan bahwa masyarakat masih memiliki kesadaran yang rendah akan sebab dan akibat dari industri fast fashion. 


\section{Komunitas Batik Mangrove}

Menurut GPS Wisata Indonesia, pada tahun 2007, pasca reformasi, terjadi pembalakan liar hutan mangrove di kota Surabaya, Jawa Timur. Kejadian ini merusak hampir 10 hektar hutan bakau di sepanjang bibir pantai dan muara Kali Saridamen, Kecamatan Mulyorejo, Wonorejo, dan di pesisir utara Surabaya.

Seorang pendidik bernama Lulut Sri Yuliani merasa tergerak terhadap kerusakan mangrove ini. Dari sinilah Lulut bersama dengan masyarakat sekitar memilau gerakan penyelamatan mangrove dengan menanam kembali kawasan dengan jenis mangrove yang sama. Tak hanya sampai di situ, beliau juga memperbaiki SDM masyarakat dengan memperkenalkan batik Mangrove dengan mangrove sebagai bahan utama pewarnanya.

Dari sinilah kemudian datang Batik SeRu atau seni Batik mangrove Rungkut Surabaya serta Koperasi Usaha Kecil Menengah (UKM) Griya Karya Tiara Kusuma yang bertujuan untuk mempromosian dan mendistribusikan produk-produk mangrove yang dihasilkan. Sampai saat ini, telah terdapat 2.017 pakem motif batik mangrove yang diharapkan kemudian muncul desain batik bertema lingkungan lainnya.

Pada tahun 2013, berdiri pula komunitas Batik Bakau yang didirikan oleh Cahyadi di mana komunitas ini merupakan green entrepreneurship yang menggunakan limbah buah bakau sebagai pewarna alami untuk membuat batik ramah lingkungan. Pada tahun 2016, seorang Dosen Fakultas Perikanan dan Ilmu Kelautan (FPIK) Undip mencoba menerapkan ilmu turunan bioteknologi yang berfokus pada pengembangan bahan pewarna dari limbah batang, daun, serta akar mangrove. Hasilnnya pada tahun 2017, beliau mendapatkan dana hibah Program HI-Link Kemenristekdikti RI. Hibah ini digunakan untuk membimbing cara pembuatan pewarna dari limbah mangrove dalam skala besar.

\section{Kelestarian Batik}

Keberadaan dan kelestarian batik menjadi hal utama yang cukup genting untuk diperhatikan. Namun, pada saat ini keberadaannya hanya dianggap sebagai pakaian resmi dan kurang diminati masyarakat. Masyarakat nampaknya lebih tertarik pada produk sandang yang mengikuti tren fashion meski pada kenyataannya, tren fashion yang begitu cepat berganti dari musim ke musim ini menghasilkan produk yang tidak ramah lingkungan. Lebih parahnya, juga tidak ramah pekerja tekstil mengingat pada beberapa kasus, produksi massal hasil sandang menggunakan bahan-bahan yang berbahaya.

\section{Rumusan Masalah}

Dilansir dari Kompas.com, kita semua tahu bahwa batik merupakan warisan dunia. Hal ini UNESCO mengakui batik sebagai warisan dunia karena memenuhi kriteria, antara lain kaya dengan symbol, seni dan makna filosofi kehidupan rakyat Indonesia. Seorang Arkeolog Belanda JLA Brandes (2017), menyatakan bahwa batik merupakan salah satu dari 10 kebudayaan asli yang dimiliki bangsa Indonesia."

Meski keberadaannya perlu dilestarikan, namun kenyataannya limbah cair produksi batik merupakan salah satu yang mencemari lingkungan. Oleh karena itu, salah satu tujuan dari pembangunan proyek ialah memberikan ruang yang lebih besar bagi komunitas batik mangrove untuk dapat semakin bertumbuh. Selain itu, juga ikut andil dalam pelestarian hutan mangrove di wilayah Tanjung Pasir.

\section{KAJIAN LITERATUR}

\section{Pengertian Batik}

Batik merupakan salah satu warisan kebudayaan Indonesia yang tidak diragukan keasliannya. Apalagi setelah dicanangkan oleh UNESCO dalam "Daftar Representatif Budaya Tidak Berwujud Warisan Manusia" atau lebih dikenal dengan "Representativev List of the Intangible Cultural Heritage of Humanity" pada tanggal 2 Oktober 2009. Batik berasal dari bahasa Jawa "amba" yang artinya menulis dan "tik" yang artinya titik. 
Menurut KBBI, batik berarti kain bergambar yang pembuatannya secara khusus dengan menuliskan atau menerakan malam pada kain, kemudian pengolahannya diproses dengan cara tertentu. Dewasa ini, batik sudah termasuk bagian dari industri tekstil modern meski hasil produksinya masih kalah populer dibandingkan dengan hasil industry fast fashion.

\section{Pengembangan Batik Mangrove}

Berdasarkan uji coba yang dilakukan oleh Prienggenies (2016) dalam membuat pewarna bernbahan limbah mangrove, diketahui bahwa dapat diperoleh hasil 1 kilogram limbah mangrove, dapat menghasilkan 10 liter cairan pewarna batik.

Dari 10 liter pewarna, dapat dihasilkan kurang lebih 5 potong kain batik berkualitas tinggi. Tahun 2017 dilanjutkan dengan memfokuskan untuk pencapaian kualitas produk. Hasilnya, batik yang menggunakan pewarna limbah mangrove dengan sentuhan teknologi sudah teruji dapat menghasilkan bahan yang lebih lembut (hand feel), mudah diserap (water absorption), sserta kriteria warna (pigment) yang tahan cuci (dye ability).

\section{Makna dan Peran Mangrove}

Menurut Bayu Galih dalam artikelnya yang berjudul Hari Ini 8 Tahun Lalu, UNESCO Akui Batik sebagai Warisan Dunia Asal Indonesia, Mangrove sendiri memiliki makna ekologis yang sangat besar, baik bagi kepentingan lingkungan maupun kepentingan manusia. Habitatnya di pesisir membantu perannya sebagai penghalang, pencegah erosi, serta melindungi dari badai, menjadi biofilter untuk nutrisi (nitrogen dan fosfor) sehingga tak dipungkiri lagi bahwa hutan bakau membentuk dasar dari rantai makanan. Mangrove disebut sebagai penyelamat pantai pesisir. Hal ini karena akarnya yang kuat menahan gelombang yang tinggi, menjadi habitat bagi banyak spesies terancam dan hampir punah (harimau royal Bengal, manate, serta penyu laut).

Selain itu mangrove memiliki peran antara lain; 1) Stabilisasi tanah dan perlindungan erosi, 2) Penyerap karbon dioksida dan penyimpan karbon dalam sedimen tanah, 3) Pelindung dari angin kencang dan ombak, 4) Pelindung garis pantai dari kerusakan akibat badai dan gelombang, 5) Penyaring sedimen dan polutan. (GPS Wisata Indonesia, 2018)

\section{METODE}

Metode perancangan yang digunakan dalam proyek ini adalah :

\section{a. Studi Literatur}

Studi Literatur yang diambil dari GPS Wisata Indonesia dan Carbon Ethics Batik Mangrove menjadi landasan memahami lebih lanjut tentang batik mangrove dan segala urgensinnya untuk dikembangkan.

\section{b. Studi Preseden}

Karya arsitektur yang dipakai sebagai referensi proyek ini ialah Jinchang Cultural Centre dan The Tjoloemadoe

\section{c. Kontekstual}

Proyek tugas akhir ini dirancang dengan menggunakan metode desain yang kontekstual di mana segala hasil rancangan disesuaikan dengan kondisi hasil dari analisis tapak.

Adapun proses desain yang dipakai terdiri dari analisis tapak, implementasi desain dan zonasi detail tapak.

1) Analisis tapak, dipakai dalam menentukan posisi strategis bangunan dan titik-titik zonasi detail tapak.

2) Implementasi desain, menggunakan filosifi batik kawung selaku batik tertua di Indonesia.

3) Deskripsi desain, digambarkan dengan diagram skematik mengenai konsep desain proyek dan kaitannya dengan melampaui ekologi. 


\section{Strategi Perancangan}

Perancangan proyek ini menggunakan konsep sustainable development program yang mengusung keberlanjutan ekologi lingkungan dengan melakukan daur ulang limbah mangrove dan limbah air batik. Keberadaan bangunan proyek ini dapat menjadi wadah bagi lingkungan untuk dapat memperbaiki dirinya (mengurangi limbah dan menjadikannya kawasan pariwisata yang berpotensi). Selain itu, juga memberikan kesempatan bagi para masyarakat untuk mengenal batik mangrove.

\section{DISKUSI DAN HASIL} Pemilihan Lokasi

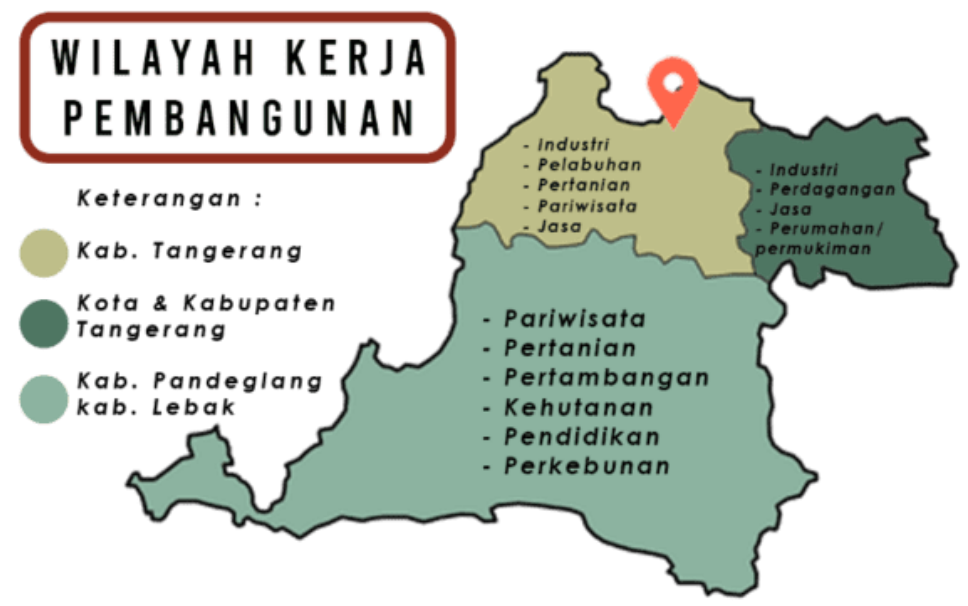

Gambar 3 Peta Wilayah Kerja Pembangunan Sumber : Dokumentasi pribadi, 2021

Lokasi yang terpilih dipertimbangkan dari tujuan proyek yaitu untuk wisata dan pengembangan hutan mangrove. Kawasan Tanjung Pasir menjadi kawasan berpotensi karena merupakan kawasan pariwisata serta merupakan kawasan yang memiliki karakteristik yang sesuai dengan habitat hutan mangrove. Tapak terpilih berada di kawasan Tanjung Pasir, tepatnya di Jalan Tanjung Pasir , Banten. Berada di zonasi C1 - Campuran dengan luas tapak 12.000 meter persegi. Terletak dekat dengan area dermaga Tanjung Pasir (bersebelahan dengan tapak).

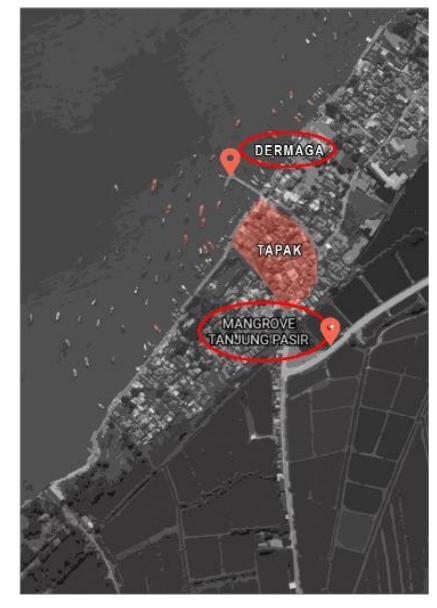

Gambar 4 Gambaran Tapak

Sumber : Dokumentasi Pribadi, 2021

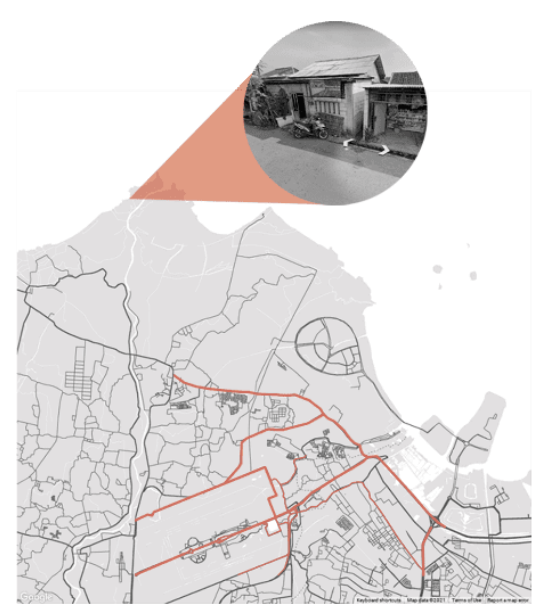

Gambar 5 Tapak Terpilih Sumber : Dokumentasi Pribadi, 2021 
Tapak memiliki KDH sebesar 40\%, KDB sebesar 40\%, serta KB (ketinggian bangunan) 3 lantai. Pemilihan lokasi tapak karena memiliki posisi yang strategis yakni dekat dengan area hutan mangrove Tanjung Pasir (berjarak kurang lebih 100 meter) serta bersebelahan dengan dermaga Tanjung Pasir. Selain itu, keberadaan tapak yang bersinggungan langsung dengan pesisir pantai menjadikannya habitat yang baik untuk hutan mangrove.

Berikut ini merupakan keberadaan lokasi eksisting.

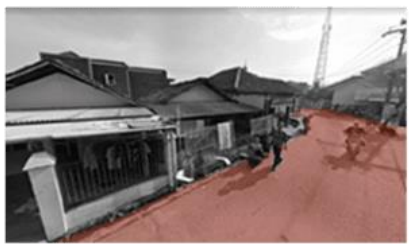

Gambar 6 Jalan Tapak

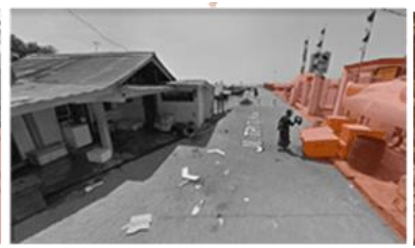

Gambar 7. Dermaga

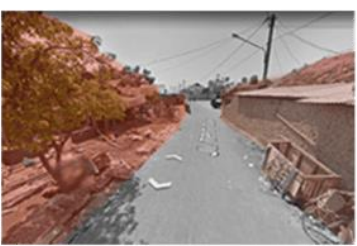

Gambar 8 Bangunan Sekitar Tapak

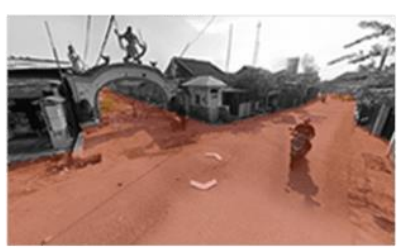

Gambar 9 Pertigaan Jalan

Sumber : Google Earth, 2021

\section{Pemrograman}

Pengguna protek ialah masyarakat sekitar Tanjung Pasir dan tidak menutup kemungkinan untuk masyarakat dari luar Tanjung Pasir. Rumah wisata batik mangrove ini ditargetkan untuk para remaja maupun keluarga.

Program di dalam rumah wisata batik mangrove didapatkan dari analisis tapak dan aspek sekuen kegiatan sehingga dihasilkan usulan program utama proyek bangunan yang terdiri dari : (1) Area wisata hutan mangrove; (2) workshop; (3) gallery batik; (4) Area komunal; (5) Servis (gudang, area cuci, area pembibitan); (6) Area marketing.

Dari perhitungan luasan peraturan pembangunan dan kelima usulan program, dihasilkan 2 program utama yakni tempat wisata hutan mangrove dan gallery batik. Kedua program ini memiliki keterkaitan satu dengan yang lainnya dan didukung dengan program keberlanjutan (sustainable program) yakni daur ulang limbah mangrove serta daur ulang limbah cairan batik dan lilin malam mbatik. Skema program ruang dan perkiraan luasan proyek dapat dilihat pada gambar 9 dan gambar 10.

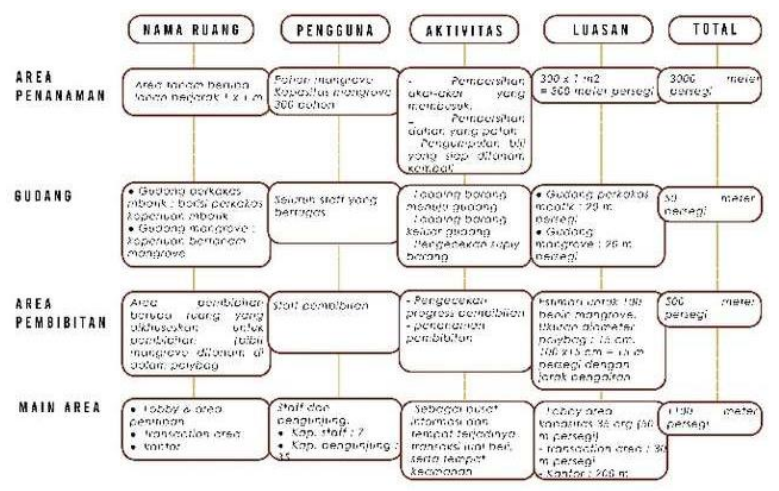

Gambar 10 Program Ruang 1

Sumber : Dokumentasi Pribadi, 2021

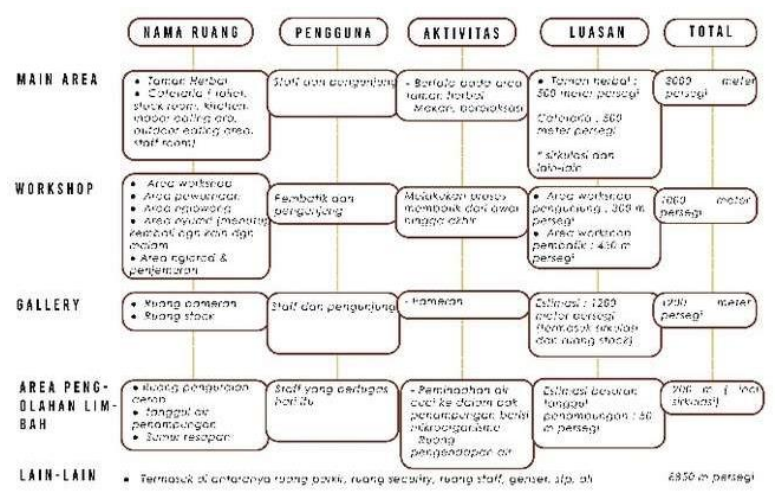

Gambar 11 Program Ruang 2

Sumber : Dokumentasi Pribadi, 2021

Adapun program utama rumah wisata batik mangrove meliputi : (1) Area wisata hutan mangrove (terdiri dari hutan mangrove serta area taman herbal) sebesar $40 \%$ atau kurang lebih $3.780 \mathrm{~m}^{2}$; (2) workshop (terdiri dari area nglorod, ngisen, nerusi, dan area mbatik dan plant workshop) sebesar $15 \%$ 
atau kurang lebih $1.600 \mathrm{~m}^{2}$; (3) gallery batik (terdiri dari rented exhibitions dan permanent gallery) sebesar $25 \%$ atau sebesar $3.790 \mathrm{~m}^{2}$; (4) area komunal (terdiri dari co-working space dan restaurant/cafetaria) sebesar $10 \%$ atau $1200 \mathrm{~m}^{2}$; (5) Area Servis (terdiri dari gudang, area cuci, dan area pembibitan) sekitar $10 \%$ atau $900 \mathrm{~m}^{2}$; dan (6) Area marketing (terdiri dari thrift shop, merchandise shop, serta plant shop) sebesar $10 \%$ atau sekitar $800 \mathrm{~m}^{2}$. Total program ruang keseluruhan ialah 11.270 $\mathrm{m}^{2}$.

\section{Pembentukan massa}

Proses pembentukan massa berawal dari pengolahan analisis tapak yang menghasilkan bentuk massa sirkular yang memudahkan sirkulasi. Selanjutnya, dilakukan pembagian zoning berdasarkan daya tangkap angin paling besar serta pasang surut air laut.
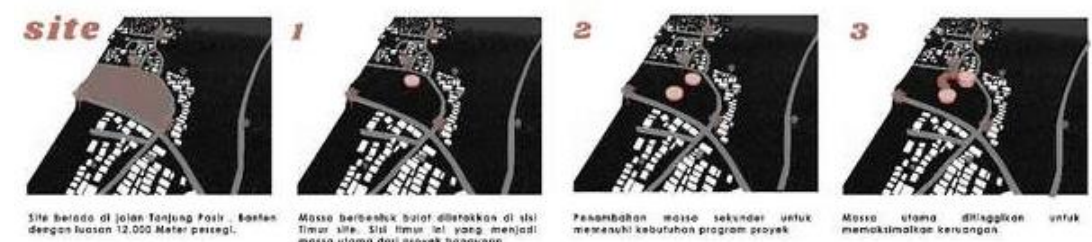

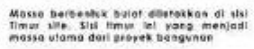

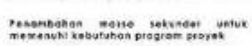

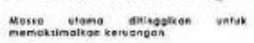
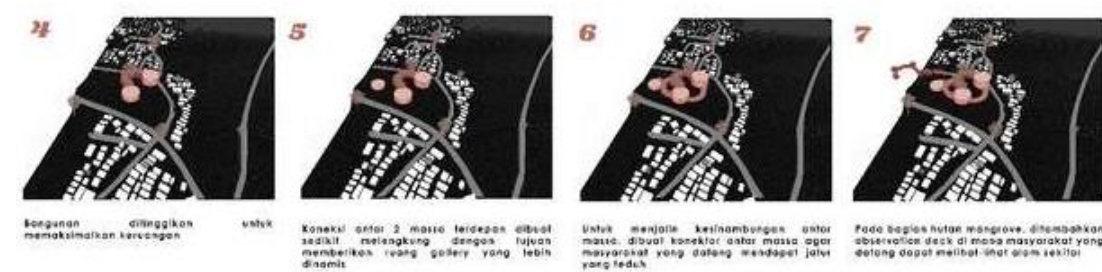

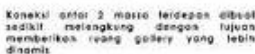

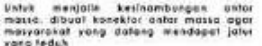

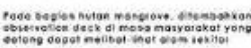

Gambar 12 Proses Gubah Massa

Sumber : Dokumentasi Pribadi, 2021

Daya tangkap angin paling

besar berada di sisi utara tapak. Hal ini nantiya akan berpengaruh pada penempatan zoning area mangrove pada tapak. Selain itu, pasang surut air laut menentukan jenis mangrove yang cocok ditanam pada area tapak serta ketinggian maksimal observation deck pada daerah hutan mangrove.

\section{Material bangunan}

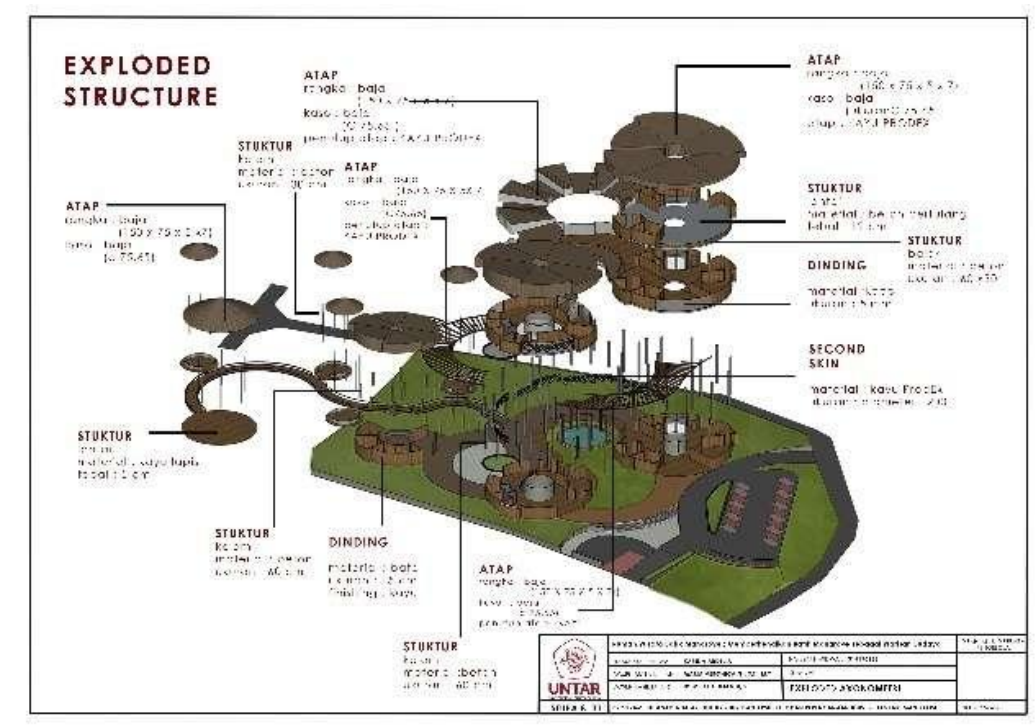

Gambar 13 Exploded Structure Proyek Sumber : Dokumentasi Pribadi, 2021 
Penggunaan material second skin façade dari ProEx, yakni sebuah produk Proderma yang merupakan salah satu perusahaan yang memproduksi sustainable wood dengan kualitas tinggi.

Kayu ProdEx bersertifikat PEFC dan diproduksi dari bahan hutan mentah melalui siklus lingkungan yang bertanggung jawab. ProdEx dilapisi dengan film PVDF yang sangat tahan untuk melindungi dari elemen eksternal (sinar matahari) dan masa perawatan jangka panjang.

\section{DESKRIPSI DESAIN}

\section{Konsep}

Isu mengenai industri fast fashion yang berdampak pada lingkungan dan ekologi jangka panjang menjadi titik berat pengembangan konsep desain bangunan. Selain itu, penempatan massa bangunan mengikuti filosofis batik kawung antara lain:

a. Bagian Barat : matahari terbenam yakni tempat keberuntungan turun. Oleh karena itu, area purchasement ( merchandise shop, thrift shop, serta plant shop) ditempatkan pada bagian barat.

b. Bagian Timur : tempat matahari terbit dipercaya sebagai pembawa keberuntungan serta titik tangkap pasang air terbaik sehingga digunakan untuk area hutan mangrove.

c. Bagian Utara : letak gunung dan dianggap sebagai area sakral. Oleh karena itu, area ini digunakan untuk daerah pengembangan hutan mangrove yang penting bagi kelangsungan hidup manusia dan lingkungan.

d. Bagian Selatan : zenit atau puncak segala hal. Oleh karena itu dibuat paling tinggi (puncak) dengan ketinggian total 12 meter ( 3 lantai).

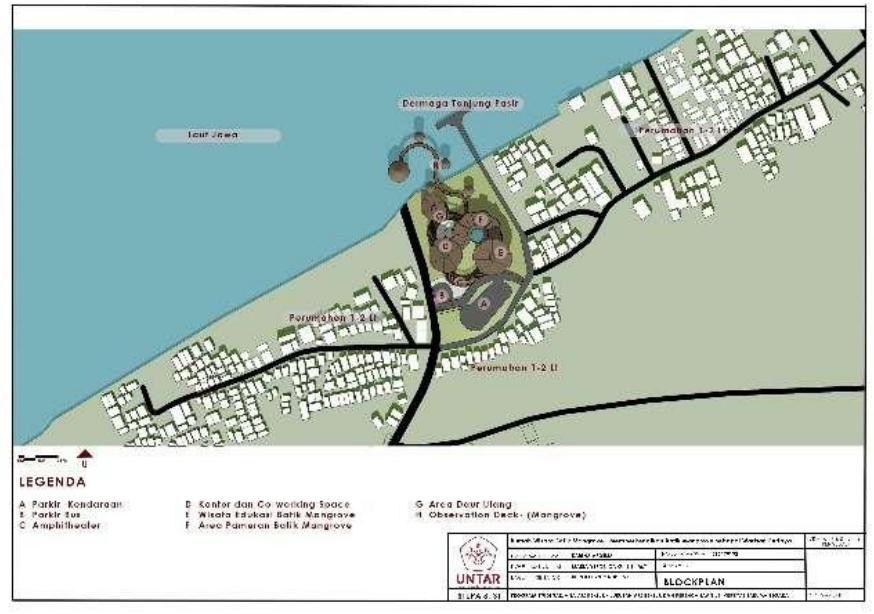

Gambar 14 Block Plan

Sumber : Dokumentasi Pribadi, 2021

\section{Hasil Desain Rancangan}

Sebanyak $40 \%$ dari area tapak merupakan area hutan mangrove dengan beberapa observation deck. Gunanya agar setiap masyarakat yang berkunjung dapat mengamati hutan mangrove dari dekat.
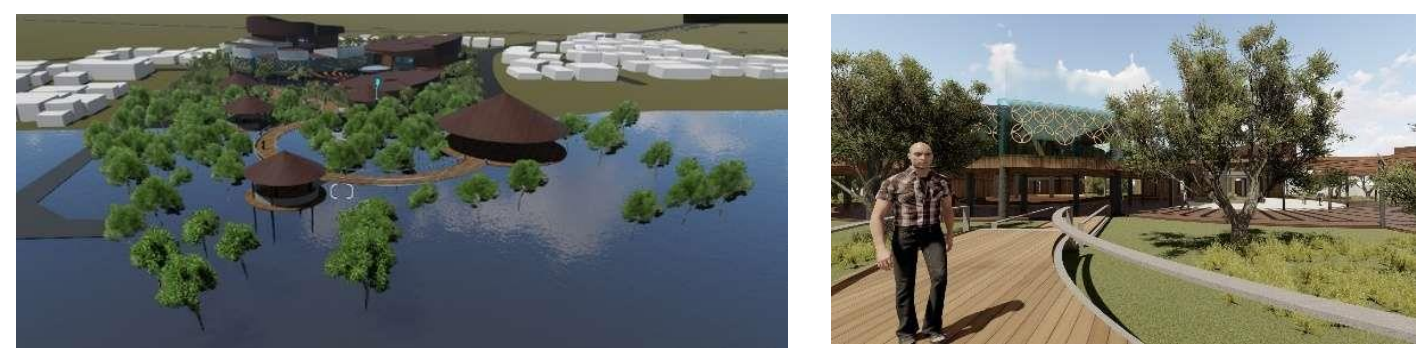

Gambar 15 Area Hutan mangrove Sumber : Dokumentasi Pribadi, 2021
Gambar 16 Jembatan Konektor Hutan mangrove Sumber : Dokumentasi Pribadi, 2021 
Pencapaian dari tapak menuju ke area hutan mangrove menggunakan jembatan kayu dengan ketinggian yang berbeda (variatif dari 1.2 meter hingga 2 meter) menyesuaikan dengan ketinggian maksimal pasang surut air laut.

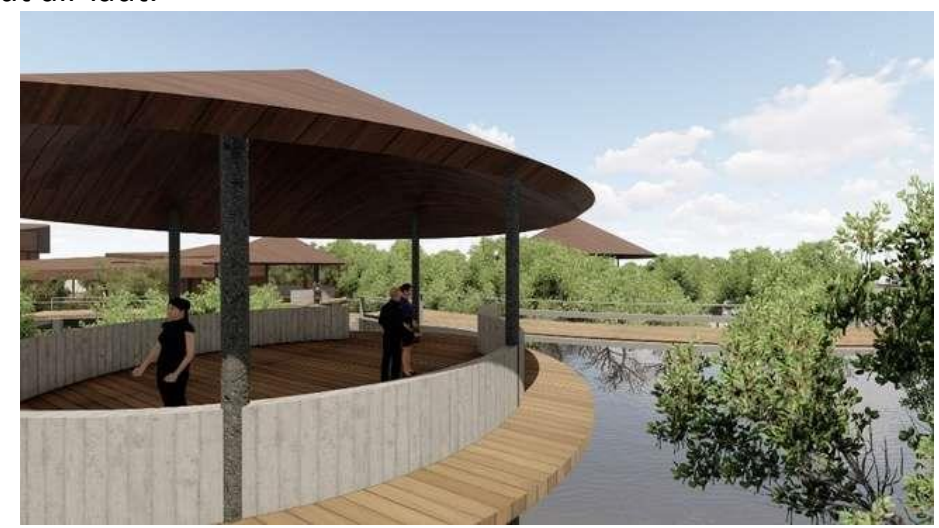

Gambar 17 .Area Observation Deck

Sumber : Dokumentasi Pribadi, 2021

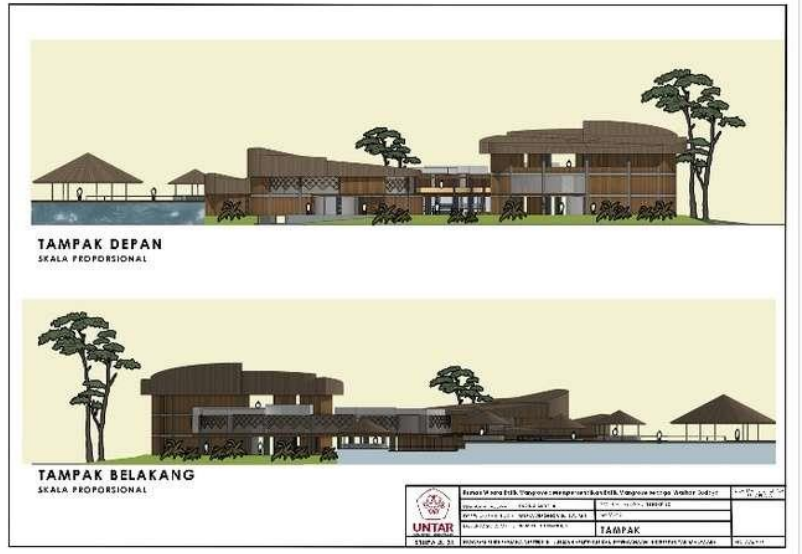

Gambar 18 . Tampak depan \& belakang Sumber : Dokumentasi Pribadi, 2021

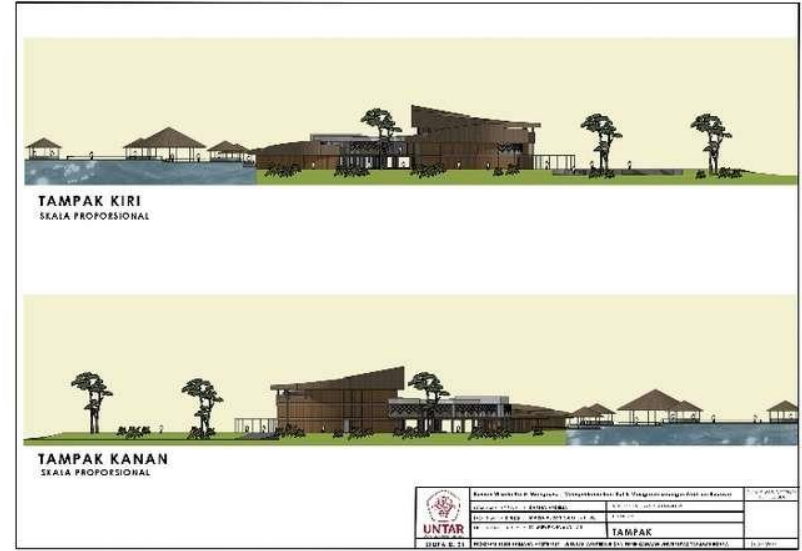

Gambar 19. Tampak kiri \& kanan

Sumber : Dokumentasi Pribadi, 2021

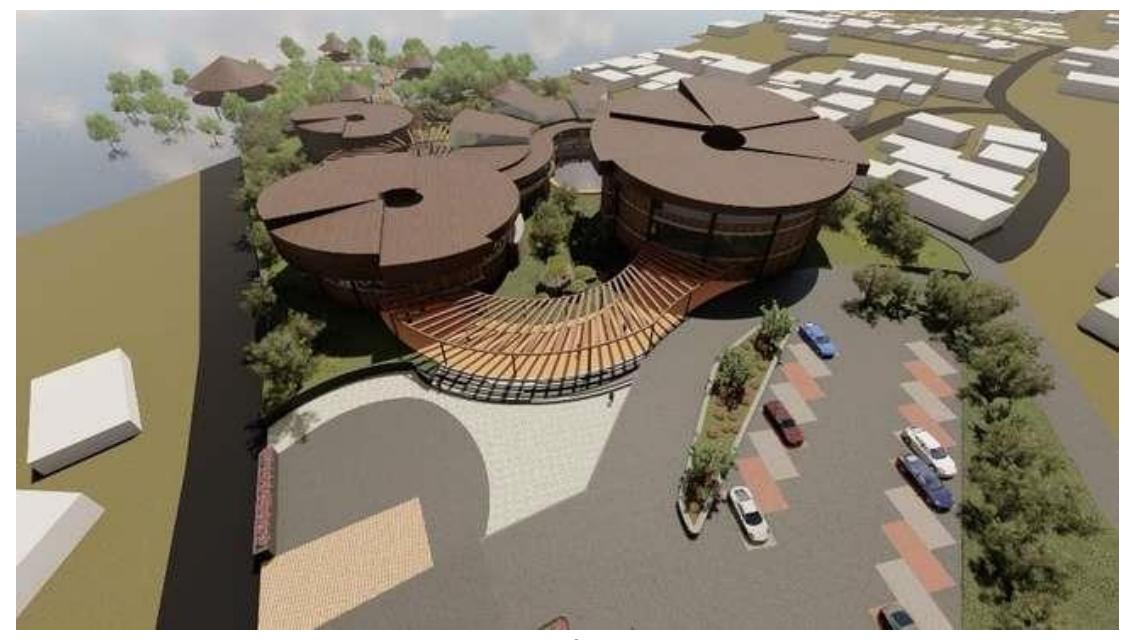

Gambar 20 Perspektif Bird Eye View

Sumber : Dokumentasi Pribadi, 2021 


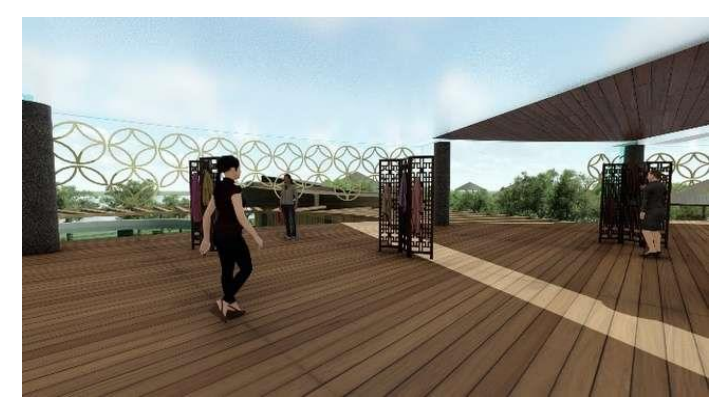

Gambar 21 Perspektif Interior Lantai Atas Gallery Sumber: Dokumentasi Pribadi, 2021

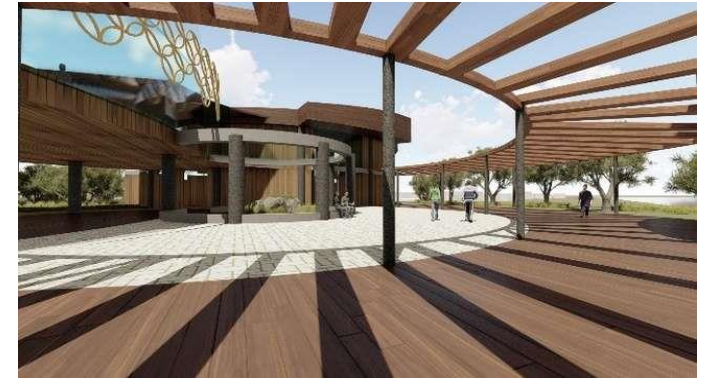

Gambar 22 Perspektif Interior Area Jemur

Sumber: Dokumentasi Pribadi, 2021

\section{KESIMPULAN DAN SARAN Kesimpulan}

Proyek gallery batik mangrove dan pengolahan limbah batik mangrove dengan nama lahir Rumah Wisata Batik mangrove memiliki tujuan sebagai salah satu solusi bagi isu limbah mangrove yang seringkali menjadi penyumbat aliran sungai. Selain itu juga sebagai solusi pengganti tren fast fashion menjadi slow fashion dengan kehadiran batik mangrove yang menggunakan lilin dan pewarna yang lebih ramah lingkungan. Rancangan ini diharapkan dapat meningkatkan antusiasme masyarakat terhadap batik yang tadinya hanya dianggap sebagai pakaian formal menjadi pakaian sehari-hari.

\section{Saran}

Proyek ini dapat diimplementasikan pada wilayah lain dengan permasalahan yang sama yakni menumpuknya limbah mangrove. Proyek ini cocok di lingkungan yang memiliki tanaman bakau / mangrove sebagai tanaman khas nya. Pembangunan proyek dapat disesuaikan dengan dengan keadaan lingkungan sekitar masing-masing dengan memperhatikan ke-khas an lingkungan tersebut.

\section{REFERENSI}

Eva, V, H, Heryoso S. (2017). Studi Karakteristik dan Peramalan Pasang Surut Tanjung Pasir. Jurnal Oseanografi Volume 6, Nomor 4, Halaman 416- 524.

lis, N. J dan Ifa M. (2019). Pengelolaan Limbah Cair Industri Batik Menggunakan Mikroorganisme di Kecamatan CLuring Kabupaten Banyuwangi. Warta Pengabdian Volume 13, Issue 3.

Nana, K. TM, Etty S., M Fakhrihun N. (2017). PEMBERDAYAAN MASYARAKAT PESISIR MELALUI PENCIPTAAN BATIK MANGROVE. ABDIMAS Vol. 21 No. 1. Diakses 27 Juni 2021

Syakir. (2018). Ekspresi Seni berbasis Lingkungan Pesisiran (Kajian Eksploratif Pengembangan Desain Batik Mangrove Semarang Sebagai Wujud Konservasi). Indonesian Journal of Conservation Volume 7 (02). Diakses 27 Juni 2021.

Purnobasuki, H. (2012). Pemanfaatan Hutan Mangrove Sebagai PenyimpanKarbon. Buletin PSL Universitas Surabaya. 28: 3-5.

https://www.mongabay.co.id/2014/08/13/batik-mangrove-cara-baru-eksploitasi-hutan-bakau/

https://www.carbonethics.org/save-batik-mangrove

https://gpswisataindonesia.info/batik-mangrove-cara-baru-eksploitasi-hutan-bakau/

https://jahidinbudi.wordpress.com/2014/04/23/pencemaran-limbah-batik-

pekalongan/\#: :text=Pencemaran\%20limbah\%20batik\%20berasal\%20dari\%20penggunaan\%20zat\%20kim ia,batik\%2C\%20makin\%20banyak\%20juga\%20penggunaan\%20zat\%20pewarna\%20kimiawi

https://kbbi.web.id/batik

https://www.downtoearth.org.in/news/environment/fashion-industry-may-use-quarter-of-world-s-carbonbudget-by-2050-61183

https://zerowaste.id/zero-waste-lifestyle/mengenal-fast-fashion-dan-dampak-yang-ditimbulkan/ https://gpswisataindonesia.info/fungsi-dan-peranan-hutan-mangrove-dalam-ekosistem-pesisir/ https://kwriu.kemdikbud.go.id/berita/hari-ini-8-tahun-lalu-unesco-akui-batik-sebagai-warisan-dunia-asalindonesia 